\title{
Hungary, the Soviet Bloc, the German Question, and the CSCE Process, 1965-1975
}

\author{
$\because \quad$ Csaba Békés
}

\section{The Tripartite Determinism of Hungarian Foreign Policy}

After the 1956 revolution, Hungarian foreign policy was determined not simply by dependence on the Soviet Union but by a more complex system of tripartite determinism. Although affiliation with the Soviet bloc imposed tight restrictions, Hungary's dependence on Western advanced technology, trade contacts, and hard-currency loans engendered another strong bond. At the same time, Hungarian foreign policymakers had to perform a balancing act to pursue specific national objectives by engaging in an "all-East-Central-

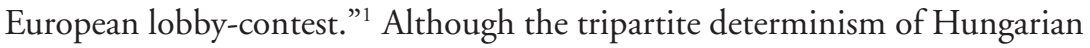
foreign policy had always existed in some form, the relative importance of the three factors converged in the mid-1960s. This same arrangement applied in large part to the entire Soviet bloc. The three factors also drove Hungarian, Polish, Romanian, East German, and (to a lesser extent) Czechoslovak and Bulgarian foreign policy, particularly from the mid-1960s onward. ${ }^{2}$

Hungary in its relationship with the Soviet Union—even after the sudden replacement of János Kádár's patron, Nikita Khrushchev, by Leonid Brezhnev in October 1964 - played the role of a loyal, dependable, and predictable partner until 1989. Two main factors justified Kádár's conviction that a staunchly pro-Soviet political line would be most advantageous. One was the exigency of bolstering Western economic relations, insofar as these relations were pivotal to the modernization of the Hungarian economy. In the 1960s, this process demanded confirmation of Hungary's unswerving loyalty as well as the

1. For an archive-based analysis of Hungarian foreign policy under János Kadar, see Csaba Békés, "Hungarian Foreign Policy in the Soviet Alliance System, 1968-1989," Foreign Policy Review, Vol. 2, No. 1 (2004), pp. 87-127.

2. For the German Democratic Republic (GDR), the Western relationship meant, above all, their unique and highly controversial relationship with the Federal Republic of Germany (FRG).

Journal of Cold War Studies

Vol. 18, No. 3, Summer 2016, pp. 1-44, doi:10.1162/JCWS_a_00654

(C) 2016 by the President and Fellows of Harvard College and the Massachusetts Institute

of Technology 
indivisibility of the bloc, as Brezhnev emphasized at a meeting of the Warsaw Pact's Political Consultative Committee (PCC) in Warsaw in January 1965: "The imperialists are trying to extend their contacts to the socialist countries to influence their domestic lives in a direction favorable to them and to undermine their unity by offering economic, technological, and scientific incentives. Hence, it is of the utmost importance to prevent their ideological penetration and subversive endeavors." ${ }^{3}$

A second and equally important factor involved the preparations for reforming the Hungarian economy. Economic reform proved to be the most significant structural change in the Soviet bloc since the establishment of the Stalinist command economic system. Hungarian leaders believed it was essential to reassure Soviet officials that reforms would apply solely to the economy. Hence, Hungarian foreign policy aimed, in light of Hungarian-Soviet relations, to apply the policy of "constructive loyalty."' The main features of this approach were conflict prevention, credibility, predictability, and flexibility with regard to political issues, as well as adjustment to Soviet requirements and a willingness to cooperate with Moscow. Throughout this period, Hungary played a mediating role in the Warsaw Pact, the Council of Mutual Economic Assistance (CMEA), and multilateral negotiations in support of long-standing Soviet goals. The "constructive" aspect of Hungary's loyalty implied that despite all these factors, the constraints could be and in fact were continually tested and gradually loosened. The implication of this principle until the late 1980s was that "what is not forbidden is (perhaps) allowed." Another important aspect of Hungary's foreign policy was that Hungarian leaders, by gaining credibility through loyalty, had leeway to try to influence Soviet policymakers and achieve concessions within the framework of bilateral relations, which served the concrete interests of Hungary as well as the other East-Central European countries in most cases. Hungary's overtures did not always yield results, but in numerous instances Hungarian leaders were able to exercise positive influence on the Soviet Union with respect to fundamental issues affecting East-West relations.

Constructive loyalty yielded another result as well. Because the fundamental long-term aims of Hungarian authorities after 1956 necessitated the maintenance of relatively independent domestic development, Soviet-Hungarian economic relations - first and foremost, the guarantee of an uninterrupted supply of Soviet raw materials and energy supplies at a "friendly" price to sustain

3. Minutes of the session of the MSzMP Political Committee, 26 January 1965, in Magyar Nemzeti Levéltár Országos Levéltára (MNL-OL), M-KS. 288, F. 5/237. őrzési egység ("̋.e.).

4. Békés, "Hungarian Foreign Policy in the Soviet Alliance System," p. 89. 
industrial production-were of paramount importance. In exchange for preventing overt political conflict with Hungary, Soviet leaders, in most cases, turned a blind eye when Hungarian negotiators were extremely tough bargaining partners during bilateral economic talks. On the whole, the Hungarians managed to extract economic concessions in return for political cooperation.

Starting in the early 1960s, Hungary's economic needs induced officials in Budapest to seek closer ties with the West. The basis of this drive was their realization that only a functioning and gradually growing economy and higher standards of living would ensure political stability, as set out in the Kádárist social contract. Rapidly advancing modern technology gained an ever-growing role in the emerging global economic environment. However, Hungary had to look to Western countries for technology because Soviet technology, with the exception of military equipment and space research, lagged behind the West from the 1950s on, and the gap steadily widened. ${ }^{5}$

Because Hungary lacked most types of raw materials and energy resources, its economy was one of the most open in the Soviet bloc and was reliant on foreign trade to a great extent. Because the bulk of Hungary's foreign trade was conducted with CMEA countries, the ever-growing need for hard currency (to pay for imports from the West), as well for loans, became a driving force behind Hungary's efforts to deepen its economic and trade relations with capitalist states, especially in Western Europe.

Western trade restrictions against the Eastern bloc via the Coordinating Committee on Multilateral Export Controls (COCOM) reinforced Hungarian leaders' desire to improve relations with the West in the hope of having the restrictions lifted. Consequently, from the mid-1960s on, Hungary-within the prevailing limits of Soviet tolerance-intensively broadened relations with West European countries and became one of the main proponents of East-West rapprochement.

\section{The Beginning of the CSCE Process and the Challenge of Ostpolitik, I 965-I 969}

By the mid-1960s, the German question had resulted in a division of the Soviet bloc into an economy-oriented sub-bloc (consisting of Hungary, Romania, and Bulgaria) and a security-concerned sub-bloc (East Germany, Poland, and

5. For a recent archive-based monograph on the functioning and the transformation of the Sovietstyle system in Hungary, see Melinda Kalmár, Történelmi galaxisok vonzásában: Magyarország és a szovjetrendszer, 1945-1990 (Budapest: Osiris Kiadó, 2014). 
Czechoslovakia). ${ }^{6}$ The countries in the first group had no serious unsettled issues with the Federal Republic of Germany (FRG) and were interested in economic cooperation, an expansion of trade, and the acquisition of cuttingedge technologies. They were thus the ones that most regretted the lack of diplomatic relations with the FRG. They found it increasingly difficult to remain in line with the security-concerned sub-bloc, which perceived West Germany as a security threat. Their inability to establish diplomatic relations with their most important Western economic partner seemed incongruous. ${ }^{7}$ In the case of Hungary, by the beginning of the 1960s, around 30 percent of the country's foreign trade was conducted with Western countries; one-quarter of that was with the FRG. West Germany was Hungary's most important Western economic partner from the mid-1950s on and remained so until 1989. ${ }^{8}$

Thus, the FRG played a crucial role in rebuilding Hungary's economic ties with Western countries. The West German-Hungarian relationship was motivated by several important factors, such as geographic proximity, surviving traditional economic links, wide command of the German language among Hungarian experts, and even a standardization system based on the German model. ${ }^{9}$ On the other hand, in the Soviet bloc's propaganda of the early 1960s, the FRG was portrayed as the most dangerous European "satellite" of the U.S. imperialists and a revanchist power seeking to obtain nuclear weapons and a revision of the 1945 European status quo. Thus, Hungarian leaders followed a dual policy: With regard to security aspects of the German question, they loyally followed the general political line of the Soviet bloc. But on economic relations, they tried to exploit the favorable situation that evolved with the emergence of détente after 1953 and especially $1955 .{ }^{10}$ For this purpose, the year

6. Csaba Békés, "The Warsaw Pact, the German Question and the Making of the CSCE Process, 1961-1970," in Gottfried Niedhart and Oliver Bange, eds., The CSCE 1975 and the Transformation of Europe (New York: Berghahn, 2008), pp. 113-114.

7. Most likely, this intra-bloc conflict was at least partly responsible for the failure of the Soviet initiative for the normalization of relations between the FRG and the East-Central European countries in one way or another, parallel to the process of establishing diplomatic relations between Moscow and Bonn in 1955 . To be on the safe side, Hungarian leaders adopted a resolution in July 1955 stipulating that Hungary-depending on the outcome of Chancellor Konrad Adenauer's forthcoming negotiations in Moscow—should enter into diplomatic relations with the FRG. See ibid., p. 125.

8. Report by János Kádár at the MSzMP Central Committee plenum, 10 August 1961, in MNL-OL, M-KS. 288, F. 4/42. ő.e.

9. For a survey of Hungarian-FRG relations, see László J. Kiss, "Az els” államközi megállapodástól a diplomáciai kapcsolatok felvételéig: A magyar-nyugatnémet kapcsolatok egy évtizede: 1963-1973," Külpolitika, Vol. 3, No. 3 (1976), pp. 40-64.

10. For a detailed explication of my concept of détente, see Csaba Békés, "Cold War, Détente, and the 1956 Hungarian Revolution," in Klaus Larres and Kenneth Osgood, eds., The Cold War after Stalin's Death: A Missed Opportunity for Peace? (Lanham, MD: Rowman \& Littlefield, 2006), pp. 213-233. I 
1963 proved to be a watershed for Hungary. In December 1962 the "problem of Hungary" was finally removed from the agenda of the United Nations (UN) General Assembly after a secret deal between the United States and Hungary. This was followed by the visit of UN Secretary General U Thant to Budapest in July $1963 .{ }^{11}$ Thant's visit was symbolic, in effect terminating the period of Hungary's diplomatic isolation after the 1956 Hungarian revolution and Soviet invasion. In the fall of 1963 , as a result of negotiations initiated by the FRG in April 1962, commercial missions were mutually established between West Germany and Bulgaria, Hungary, Poland, and Romania-a spectacular result that ushered in a new chapter in Hungarian-West German relations. ${ }^{12}$

Within the Soviet bloc, positions on European security-especially on the German question-were roughly the same as those concerning economic ties. Hungary conducted a specific type of pragmatic politics within the bloc, determined by the country's ultimate interests. Efforts to foster détente became an important priority for Hungarian leaders from the mid-1960s onward. One of Hungary's prime foreign policy goals was to ensure that the détente process would be irreversible.

The first policy paper on Hungary's international relations reflecting this determination was prepared just half a year after the PCC's Bucharest declaration in July 1966. ${ }^{13}$ In January 1967, Foreign Minister János Péter submitted a comprehensive proposal to the Political Committee (Politikai Bizottság) of the Hungarian Socialist Workers' Party (Magyar Szocialista Munkáspárt, or MSzMP) calling for Hungary to play an important role in the intensification of the détente process and the far-reaching improvement of East-West relations. ${ }^{14}$ To facilitate the convening of a European security conference, Péter

argue that the rapprochement process from 1953 to 1956, far from being just a promising but misfired attempt to establish détente (as generally depicted), was a major landmark that caused a decisive change in East-West relations.

11. On the secret U.S.-Hungarian talks, see János Radványi, Hungary and the Superpowers: The 1956 Hungarian Revolution and Realpolitik (Stanford, CA: Hoover Institution Press, 1972); and László Borhi, Iratok a magyar-amerikai kapcsolatok történetéhez: 1957-1967 (Budapest: Ister, 2002).

12. On the talks between the FRG and Hungary in 1962-1963, see Mihály Ruff, "A Magyar-NSZK kapcsolatok 1960-1963: Ưtkeresés a doktrínák útvesztójében,” Múltunk, Vol. 44, No. 3 (1999), pp. 3-40. In the case of Hungary and Poland, a Polish and a Hungarian commercial bureau had already operated in Frankfurt since 1946. An agreement in 1963 allowed the FRG to open similar missions in Budapest and Warsaw that were each given diplomatic status.

13. For a detailed account of the Soviet bloc's policy on European security issues, see Csaba Békés, "The Warsaw Pact and the Helsinki Process: 1965-1970," in Wilfried Loth and Georges-Henri Soutou, eds., The Making of Détente: Eastern and Western Europe in the Cold War: 1965-75 (London: Routledge, 2008), pp. 201-220.

14. Memorandum from János Péter to the MSzMP Political Committee on issues of European peace, security, and cooperation, 17 January 1967, in MNL-OL, M-KS. 288, F. 5/415. o.e. 
proposed establishing intensive official and personal contacts primarily with Austria, Great Britain, and France, but also with other West European countries such as Belgium, Denmark, the Netherlands, and Norway. The most radical component of the proposal was the establishment of a framework for close cooperation among "the countries of the Danube Valley and the Central European states" (Hungary, Czechoslovakia, Yugoslavia, and Austria).

In all probability, Péter was the only Hungarian foreign minister from 1945 through 1989 who considered his post to be more than a political function bound to professional circumstances. His "Danube Valley" idea was almost expressly aimed at rebuilding the regional ties of the former AustroHungarian monarchy, which had once proved to be a rational and effective model of cooperation. Thus, by early 1967, Péter was already capable of prognosticating a transformation of East-West relations radical enough to make close cooperation possible between states from opposing social systems. Péter, who probably considered lobbying for this idea to be his personal mission, had made numerous attempts to convince Soviet leaders of this up to the early 1970s, using the rationale (among others) that a neutral Austria might be drawn closer to the Eastern bloc. ${ }^{15}$ Although détente resulted in an unprecedented rapprochement between the two camps in the following years, the "Danube Valley" idea was not acceptable to Moscow either then or later. Soviet leaders instinctively worried about the potential negative consequences of any specific East-Central European regional coordination that did not include the USSR.

Nonetheless, the plan of January 1967 unambiguously signaled the desire of Hungarian foreign policymakers to participate actively and in an innovative way in the process of transforming East-West relations. After the PCC's declaration in Bucharest in July 1966, Hungarian diplomats-with encouragement from the Soviet Union-launched a large-scale campaign to initiate bilateral negotiations with West European partners, promoting the idea of a European security conference. From 1966 to 1969, talks were conducted with numerous states at the level of foreign ministers, deputy foreign ministers, and foreign policy experts. In March 1968, the first visit by a Hungarian prime minister to Western Europe took place since 1946: Jenő Fock conducted talks with French President Charles de Gaulle and Prime Minister Georges Pompidou in Paris.

The Soviet Union's decision in the mid-1960s to seek improvements in East-West relations thus coincided fully with the interests of Hungarian leaders.

15. Report to the MSzMP Political Committee and to the government on the visit of Foreign Minister János Péter to the Soviet Union, 22-29 December 1969, 6 January 1970, in Foreign Ministry (henceforth KÜM), MNL-OL, XIX. J-1-j-Szu-00949-1/1970. 
The explicit purpose of the Soviet bloc's campaign was an all-encompassing effort to set in motion one of the most important strategic targets of the period-namely, the staging of a European security conference that would legitimize the post-1945 European status quo. Meanwhile, by pursuing bilateral negotiations, the East-Central European states, including Hungary, could "legally" augment their ties with the West and acquire negotiating experience they had never had before. From then on, as the Soviet Union attempted to advance the role of its allies in world politics, Soviet leaders came to regard them as partners, albeit in a limited sense. This development resulted in unprecedented international activities for some of the East-Central European countries-namely, Poland, Hungary, and Romania-which in turn enhanced their standing both within their own alliance and in East-West relations generally.

Hungary's role in the Eastern bloc thereby received a lasting boost. Although Hungary started at a serious disadvantage because of 1956, this handicap had disappeared by the mid-1960s, and the country became a model state for the West because of its de-Stalinization and relative internal liberalism. The Hungarian government's increasingly important role in international politics was strengthened further in 1968 when Hungary became a non-permanent member of the UN Security Council for two years. Despite Kádár's decision to take part in the invasion of Czechoslovakia in August 1968, Western countries continued to judge Hungary by its earlier performance. Hence, Hungary gradually assumed an important position alongside Romania and Poland in seeing improvements in East-West relations and pushing for a European security conference. Hungary's role was enhanced by the inception of the country's "New Economic Mechanism," launched in January 1968, which was favorably perceived in the West as a shift toward a more market-oriented economy. Meanwhile, the anti-Semitic campaign that emerged in Poland after the 1967 war in the Middle East indisputably damaged the international standing of the Polish government.

\section{A Missed Opportunity: The Challenge of Establishing Diplomatic Relations with the FRG, I 966-I 968}

When the resolution of the German question emerged at PCC meetings in January 1965 and July 1966, Hungarian leaders loyally adopted the Soviet position and fully supported efforts to gain international recognition of the German Democratic Republic (GDR). However, the joint Warsaw Pact position 
worked out at the Bucharest PCC conference was interpreted by Hungarian officials as a call for opposing the FRG's Hallstein Doctrine, which sought to isolate the GDR.

Consequently, when the new Grand Coalition government in West Germany headed by Chancellor Kurt Kiesinger and Foreign Minister Willy Brandt initiated secret preliminary talks with four countries (Czechoslovakia, Hungary, Romania, and Bulgaria) in December 1966 in an attempt to establish diplomatic relations, Hungarian leaders were eager to respond positively. ${ }^{16}$ This step signaled a radical turning point in the foreign policy of the FRG insofar as it would lead to the abandonment of the Hallstein Doctrine and a victory for the Soviet bloc. In return for this significant concession, the West Germans asked the four countries to consider the "Moscow model" as the basis for establishing official relations without preconditions-a model in line with the FRG's long-standing position on the German question. In October, Hungarian leaders backed the Polish leader Władysław Gomułka in urging the PCC to hold a consultative meeting on European security, but Romania’s opposition prevented it. ${ }^{17}$ Hence, the East European countries pursued separate policies while seeking to harmonize their standpoints with Moscow Hungarian leaders informed the Soviet Union and other Warsaw Pact states about the negotiations with the FRG but received ambiguous responses, if any. Nonetheless, no country, not even the GDR, flatly rejected the Hungarian position. The lack of a negative reply was construed by Hungarian officials as outright approval. The MSzMP Political Committee adopted a resolution on 10 January 1967 to begin official negotiations with the FRG. ${ }^{18}$ On the basis of this authorization, Rolf Lahr, a senior West German Foreign Ministry official, conducted negotiations in Hungary from 23 to 26 January 1967, and Hungarian leaders were ready to establish diplomatic relations.

Soviet leaders at the time also favored moving ahead on the basis of the "Moscow model." However, East German and Polish leaders reacted with alarm and immediately began to lobby Moscow to block the plan. ${ }^{19}$ At a meeting in eastern Poland in late January 1967, Gomułka tried to pressure Brezhnev by

16. For a detailed account of the Warsaw Pact's policy concerning the German question, see Békés, "The Warsaw Pact, the German Question and the Making of the CSCE Process," pp. 113128.

17. MSzMP Political Committee resolution of 27 October 1966 agreeing to this proposal, in MNLOL, M-KS. 288, F. 5/408. ő.e.

18. Minutes of the MSzMP Political Committee, 10 January 1967, in MNL-OL, M-KS. 288, F. 5/414. ö.e.

19. Oliver Bange, “Ostpolitik und Détente: Die Anfänge 1966-1969," Habilitation Diss., Mannheim University, 2004, pp. 73-78, 136, 257. 
threatening that such a move would lead to the disintegration of the Warsaw Pact. He told Brezhnev that if the Soviet Union did not prevent the allies from proceeding, a meeting of the PCC should be convened. Brezhnev finally gave in, promising that within a few days an extraordinary meeting of the Warsaw Pact foreign ministers would deal with the matter. ${ }^{20}$ Before this step could be taken, however, Romania suddenly announced on 31 January-without any consultation with its Warsaw Pact allies—that it would be establishing diplomatic relations with the FRG.

The Romanian move was harshly criticized in the GDR press, and an unprecedented public debate ensued between East Berlin and Bucharest. In the face of this intrabloc crisis, an extraordinary meeting of Warsaw Pact foreign ministers was convened in Warsaw. ${ }^{21}$ Péter, as Hungarian foreign minister, took part with instructions that, for tactical reasons, the establishment of diplomatic relations with the FRG might have to be postponed as a consequence of Romania's unilateral step. At the same time, Peter argued that the Warsaw Pact should reach agreement on how the other member-states could establish diplomatic relations at a somewhat later time-perhaps in a few months' time. This idea fell by the wayside under relentless pressure from the GDR and Poland, with Soviet assistance. Instead of adopting Hungary's flexible tactical proposal, the participants embraced a secret protocol that came to be called the "Warsaw diktat."

The protocol stated that for the East European countries that had not yet established diplomatic relations with the FRG, conditions were no longer suitable for proceeding unless the West Germans fulfilled six preconditions: (1) renunciation of the principle of sole representation of the German nation; (2) recognition of the GDR; (3) recognition of existing borders-including the Oder-Neisse line; (4) recognition of West Berlin's special status and its independence from the FRG; (5) renunciation of the possession of nuclear weapons; and (6) recognition of the invalidity of the Munich agreement ab initio. ${ }^{22}$ East German and Polish officials insisted that the FRG could (with due persistence) be forced to recognize the GDR within a few years, renouncing

20. Douglas Selvage, "The Warsaw Pact and the German Question, 1955-1970," in Mary Heiss and Victor Papacosma, eds., NATO and the Warsaw Pact: Intrabloc Conflicts (Kent, OH: Kent State University Press, 2011), pp. 183-184.

21. Under the circumstances, the original venue of East Berlin was not acceptable for Romania.

22. Guidelines for the forthcoming negotiations with the FRG, 17 March 1967, in MNL-OL, KÜM, XIX-J-1-j, Box 70. On the Polish position, see Wanda Jarzabek, "Hope and Reality: Poland and the CSCE: 1964-1989," CWIHP Working Paper No. 56, Cold War International History Project, Washington, DC, May 2008. 
its claim to be the sole representative of the German people and accepting the European borders as settled after World War II. ${ }^{23}$

Hungarian leaders were shocked that their plans could be so easily derailed by their allies. When the MSzMP Political Committee met on 13 February 1967, a vehement debate developed concerning the Warsaw diktat and possible reactions to this humiliating situation. ${ }^{24}$ Although Hungarian leaders had been accustomed to complying with actions led by the Soviet Union-even if they did not agree with them-this was the first time such a major sacrifice was required not by direct pressure from Moscow but by the pressure of other Warsaw Pact states. ${ }^{25}$ This episode marked the gravest alliance-related crisis for Hungary since 1956. None of the members of the MSzMP Political Committee regarded the six points of the Warsaw diktat as realistic. Eventually, they decided that, to maintain the unity of the Warsaw Pact, Hungary would have to make clear its own position to its allies. Although they did not propose to renounce the joint resolution accepted in Warsaw, they disagreed with the main thesis of the protocol because consultation on the matter of establishing diplomatic relations with the FRG should have been left open. In the end, however, the situation remained largely unchanged. The Hungarian plan to normalize relations with Bonn was sacrificed for the common interests of the Soviet bloc. ${ }^{26}$

The stance taken by the GDR and Poland may have seemed unduly rigid and inflexible, but ultimately it was vindicated. The results the East Germans had been hoping for were achieved in a relatively short period of time. If the FRG had set up relations with Hungary, Poland, and Czechoslovakia along the lines advocated by Hungary, this most likely would have significantly altered the general settlement of the German question. Even the outcome of the West German elections in September 1969-in which the Social Democratic Party (SPD) prevailed—could have been called into question. If the FRG had achieved such an important diplomatic victory by applying a flexible policy without making basic concessions, this could have been a model for a successful FRG strategy in the future, with important implications for the entire process of détente.

23. Minutes of the MSzMP Political Committee session, 13 February 1967, in MNL-OL, M-KS. 288, F. 5/417. o.e.

24. Ibid.

25. On the Polish and East German positions, see Selvage, "The Warsaw Pact and the German Question: 1955-1970," p. 184.

26. In December 1973, Hungary became the last Warsaw Pact member-state to establish diplomatic relations with the FRG. 
The preconditions set forth in the Warsaw protocol were publicly reinforced by the declaration of the Conference of the European Communist and Workers Parties in April 1967. This seemed to end any hopes the Hungarians might have had of altering the joint Warsaw Pact position in the near term. Nonetheless, an unexpected opportunity emerged when far-reaching political changes began in Czechoslovakia in January 1968. The new leader of the Communist Party of Czechoslovakia (KSČ), Alexander Dubček, came forth as an ally of Kádár in the task of improving relations with West Germany. When the two leaders met in Komárno on 4 February 1968, they discussed relations with the FRG at great length. Kádár noted, with great relief, that the Czechoslovak and Hungarian points of view were identical. He felt sure that he had found an ally in Dubček on a question of critical importance for the Hungarian economy.

Kádár and Dubček were pleased that diplomatic relations had been reestablished between West Germany and Yugoslavia. ${ }^{27}$ This made three Communist countries (the Soviet Union, Romania, and Yugoslavia) that had official relations with the FRG. Dubček's agreement caused Kádár to hope that, with help from Czechoslovakia, the time might come for the Warsaw diktat to be revoked. Kádár used open, flexible language when making this point to Dubček:

We have accepted this agreement and support it without any emotional involvement either way. It came into being under adverse circumstances. The position it creates is a rigid one, and the six points [of the Warsaw protocol] give the impression that we expected the FRG to proclaim itself a Soviet republic. The conditions are over-the-top and too rigid. I said that we were of course going to support the agreement, but afterward we informed all the parties concerned that this question was not going to go away. It continues to be on the agenda. The situation must be reviewed constantly-and the same applies to what needs to be done about it. It's not one of those problems that can be dealt with once and for all. And we cannot afford not to be able to come up with political answers to political questions.

Dubček and a senior KSČ official responsible for international affairs, Vladimír Koucký, were in full agreement with Kádár. ${ }^{28}$ That Kádár pinned his hopes of bringing about a review of the Warsaw Pact's attitude toward the FRG on Dubček's mediation helps to explain why the Hungarian leader insisted

27. Yugoslavia was one of the two "victims" of the Hallstein Doctrine. After Belgrade recognized the GDR in 1957, the FRG broke off diplomatic relations with Yugoslavia. (The same happened to Cuba in 1963.)

28. Minutes of the MSzMP Political Committee, 13 February 1967, in MNL-OL, M-KS. 288, F. 5/445. ö.e. 
for so long that Czechoslovakia's consolidation in the Soviet bloc be carried out under Dubček rather than under the hardline "healthy forces" backed by Moscow. ${ }^{29}$

\section{The German Question and the Issue of European Security and Cooperation}

Following the Soviet-led invasion of Czechoslovakia in August 1968, all hopes Kádár once had of finding allies to push for a more flexible Warsaw Pact position on the German question vanished. Hungarian officials had little choice but to reevaluate their strategy and tactics on the German issue. They had not totally abandoned hope that the situation might improve through mutual concessions from both the FRG and the Soviet bloc. But by the summer of 1969 they sensed that diplomatic relations with the FRG could not be established until after the Warsaw preconditions had been fulfilled.

Thus, Hungary hoped that substantial progress in the settlement of the German question would enhance its chances of normalizing relations with the FRG. Up to this point, Hungary's position on the matter had been swayed by external pressure from the security-concerned sub-bloc within the Warsaw Pact. But Hungary's effort to settle the German problem and achieve the desired normalization increasingly came under its own control.

At this juncture, another opportunity emerged for Hungary, thanks to the unexpected acceleration of the Conference on Security and Cooperation in Europe (CSCE) in which Kádár played an important role. The Budapest Declaration of the Warsaw Pact, issued at the PCC session on 17 March 1969, became a milestone in the history of East-West relations. This initiative commenced the process that led to the signing of the Helsinki Final Act in August 1975. This was both a novelty and a success because - contrary to the Bucharest declaration of 1966-it called on the European countries to hold a security conference without setting any preconditions.

We now know that the Budapest Declaration was not the result of wellorganized and synchronized preparation as depicted in the mass media at the time. In truth, it was a document published by the Warsaw Pact member-states at the end of a surprisingly brief political coordination process, comprising

29. On Hungary's role during the Prague Spring, see Csaba Békés, "Hungary and the Prague Spring," in Günter Bischof, Stefan Karner, and Peter Ruggenthaler, eds., The Prague Spring and the Warsaw Pact Invasion of Czechoslovakia: 1968 (Lanham, MD: Lexington Books, 2010), pp. 371-395. 
numerous elements that were improvised after fierce debate among the participants. $^{30}$

The visible and rather spectacular outcome of the Budapest meeting, enacting the first major reform in the military structure of the Warsaw Pact and issuing a promising appeal for a conference on European security, was based on a de facto Soviet-Hungarian-Romanian coalition. ${ }^{31}$ The main achievement of the meeting was that the Soviet- and Hungarian-sponsored proposal, stipulating that no precondition should be set for the convening of a European security conference, was eventually accepted by all parties despite initial opposition from Polish and East German leaders. The inclusion of this unified stance of the Warsaw Pact states became a crucial factor in the initiation of the CSCE process. $^{32}$

Despite having played a critical role in mediating this historical compromise, Hungarian leaders initially failed to recognize the significance of the Budapest Declaration in shaping world politics. They did not understand the full potential of the initiative until well after the session, particularly at the end of March when the Soviet Union launched a new campaign in support of the security conference. At this juncture the Hungarians realized that the declaration - in a favorable environment-could become the basis for launching a process that would lead to the staging of CSCE.

Consequently, in July 1969, Hungarian leaders adopted a resolution regarding Hungary's relations with the FRG, which stipulated that the road toward normalization would determine the general settlement of the German question. ${ }^{33}$ At the same time, encouraged by the success of the Budapest Declaration, Hungarian foreign policymakers began to focus on promoting the start of CSCE. Kádár discerned a connection between the CSCE project and the German issue and hoped that progress on the security conference would enhance Hungary's chances of normalizing relations with the FRG.

30. For a detailed account of the secret talks preceding the Warsaw Pact PCC session, see Békés, "The Warsaw Pact and the Helsinki Process," pp. 201-220.

31. Malcolm Byrne and Vojtech Mastny, eds., A Cardboard Castle? An Inside History of the Warsaw Pact: 1955-1991 (Budapest: CEU Press, 2005), pp. 323-329. On the position of the Romanian delegation at the Budapest meeting, see "Stenographic Transcript of the Meeting of the Executive Committee of the Central Committee of the Romanian Communist Party, 18 March 1969," in A Cardboard Castle?, ed. Byrne and Mastny, pp. 332-338.

32. The paragraph on the German question included all the preconditions set forth in the Bucharest Declaration of July 1966. However, these demands were now presented in the appeal as eventual political goals and not as preconditions to the staging of a conference on European security.

33. Minutes of the MSzMP Political Committee, 1 July 1969, in MNL-OL, M-KS. 288, F. 5/493. ő.e. 
After the PCC meeting in Budapest, the Soviet Union conducted an intensive campaign from the end of March to propagate the need for CSCE. ${ }^{34}$ Although the CSCE Final Act was not signed until 1975, declassified records indicate that the foundations of the process were laid during the one-and-a-half year period between the two Budapest sessions of the PCC.

The issue of the security conference occupied an exceptional position because of prolonged preparatory work on the matter undertaken during the Communist and Workers Parties conference held a few months later in Moscow in June 1969, as well as the security conference's featured position in the final document of the conference. But what really allowed CSCE to begin were important changes in Western policy. After assuming the U.S. presidency in January 1969, Richard Nixon established a back-channel with Moscow via Henry Kissinger. At a session of the North Atlantic Council in April 1969, Nixon spoke positively about new opportunities for an East-West rapprochement. ${ }^{35}$ An equally important development followed when the SPD, together with the Free Democratic Party (FDP), formed a government after the September 1969 FRG elections and announced a new Ostpolitik. Thus, the two key Western countries-the United States and West Germany-shifted considerably from their earlier positions, thereby enhancing the chances of the Warsaw Pact's initiatives. ${ }^{36}$

In the intensive Soviet-bloc campaign in 1969 to promote a pan-European security conference, the Hungarians became one of the staunchest backers of Soviet diplomacy. Hungary's interests basically aligned with those of the Soviet Union in fostering an East-West rapprochement. Hungarian leaders had no interest in establishing preconditions for a European settlement (unlike Poland, Czechoslovakia, and the GDR) and thus could benefit only if the process succeeded. They had forged contacts with Western Europe and attained a certain level of prestige as promoters of détente. The Hungarians were innovative and ready to take the initiative, but they were also good partners who loyally, flexibly, and reliably accommodated Soviet tactical requirements. The East Germans and Poles, not to mention the Romanians, were much

34. Soviet information about the Soviet foreign ministry's activities regarding the European security conference, 1 April 1969, in MNL-OL, KÜM, XIX. J-1-j-VSZ-VI-1-001547/3/1969, Box 106.

35. On U.S. policy, see David C. Geyer and Douglas E. Selvage, eds., Soviet-American Relations: The Détente Years: 1969-1972 (Washington, DC: U.S. Government Printing Office, 2007).

36. On the Helsinki process, see three excellent, recently published edited volumes: Bange and Niedhart, eds., Helsinki 1975 and the Transformation of Europe; Loth and Soutou, eds., The Making of Détente; and Andreas Wenger, Vojtech Mastny, and Christian Nuenlist eds., Origins of the European Security System: The Helsinki Process Revisited, 1965-75 (London: Routledge, 2008). 
less manageable, often adhering to their own rigid ideas about an appropriate agenda for CSCE.

At the end of September 1969, Soviet leaders indicated that the Warsaw Pact foreign ministers would hold a conference the next month. The main task would be to arrive at a common position on CSCE. In preliminarily testing the opinions of the individual states, several Soviet deputy foreign ministers made simultaneous visits to the member-states. On 26 September, Leonid Ilichev held talks with Hungarian Foreign Minister Péter in Budapest. Ilichev proposed that the two main items on the CSCE agenda should be the renunciation of the use of force and a declaration urging the development of economic, trade, and technological-scientific cooperation among the European states. ${ }^{37}$ The MSzMP Political Committee met on 7 October and directed the Ministry of Foreign Affairs to elaborate the Hungarian position. The proposal, which was ready by mid-October, contained a remarkable number of independent suggestions that, according to the ministry, served the purpose of "presenting the... ideas of the European socialist countries in a more attractive and meaningful way," making the persuasion of uncertain states easier. ${ }^{38}$ The document suggested the following:

As an addition to the first item on the agenda, there should be a debate on the European security system and its institutions addressing the following topics:

- the signing of bilateral and regional agreements (e.g. between the countries of the Danube Valley);

- the preparation of an agreement on European security suggested by the Poles;

- the establishment of a series of conferences on European security, the creation of a European Security Council responsible for European security issues, and the linkage of the European Economic Council to the European Security Council.

With regard to the second item on the agenda, the proposal additionally suggested:

- the elaboration of a system of European economic cooperation (which would involve the linking of European systems of electricity, natural gas, oil, postal service, and telecommunications, the harmonized improvement of European transportation networks, the promotion of industrial

37. Notes on the discussion with Soviet Deputy Foreign Minister L. F. Iljichev, 27 September 1969, in MNL-OL, KÜM, XIX. J-1-j-Szu-1-00358-20/1969, Box 85.

38. Foreign Ministry memorandum on the European Security conference for the MSzMP Political Committee, 13 October 1969, in MNL-OL, M-KS. 288, F. 5/501. ő.e. 
cooperation, the harmonization of standards, and the abolition of trade barriers and encouragement of tourism);

- the setting up of a Committee for European Economic Cooperation or steps to ensure that the UN European Economic Commission functioned in accordance with the guiding principles of the conference on European security;

- the convocation in Budapest of a conference of mayors of European capitals to debate issues of better cooperation between the capitals and of common municipal problems.

Finally, for the purpose of consolidating foreign policy coordination, the proposal suggested that, after the Warsaw Pact foreign ministers gathered in Prague, a meeting of Soviet-bloc Central Committee Secretaries should be organized to discuss CSCE.

The Hungarian document was ambitious and rather bold in its ideas about European cooperation. Numerous points addressed methods of cooperation that did not become feasible until after the end of the Cold War in 1989-1990 or until Hungary's accession to the European Union in 2004. The Hungarian draft constituted a medium- and long-term "package" rather than a limited program to satisfy the tactical requirements of the initial phase.

Although the Polish, Romanian, and East German proposals were all aimed at strengthening European security, the Hungarian proposals dealt mainly with European cooperation. Thus, Hungarian diplomacy-only in formal accord with Soviet intentions - essentially followed the Western strategy of emphasizing cooperation. Perhaps the most important "relation" in which these ambitious plans would have been implemented-albeit one not specified in the proposals - was the Hungarian-FRG relationship, based on the dominant status of the FRG among Hungary's Western economic partners at that time.

After holding preliminary bilateral consultations, Soviet leaders realized that establishing a unified position at the upcoming meeting of foreign ministers - even without the expected attitude of the Romanians — would not be so easily achieved. Thus, on 17 October, Soviet Deputy Foreign Minister Vladimir Semenov requested an urgent personal conferral with the Hungarians. The following day, Hungarian Deputy Minister Károly Erdélyi met with Semenov in Moscow. ${ }^{39}$ The Soviet Union worried that because of divergent

39. Notes by Deputy Foreign Minister Károly Erdélyi for the MSzMP PC, 18 October 1969, in MNL-OL M-KS-288, F. 5/501. "̋ e. The document is published in Csaba Békés and Anna Locher, eds., Hungary and the Warsaw Pact: 1954-1989: Documents on the Impact of a Small State within the Eastern Bloc (Zurich: Parallel History Project on NATO and the Warsaw Pact, 2003). 
Polish, Romanian, and East German suggestions, the Warsaw Pact could not reach consensus and would lose control of the security conference initiative in spite of the favorable international circumstances. Therefore, in the framework of the "special relationship" evolving at this time, Soviet leaders asked their Hungarian counterparts to act in restraining the excessive Polish, East German, and Romanian proposals that would be voiced at the forthcoming meeting of Warsaw Pact foreign ministers in Prague. Set for 30-31 October 1969, the meeting was convened to reconsider Soviet-bloc policy in light of the SPD victory in West Germany the previous month. ${ }^{40}$ The Polish proposals sought to recognize the territorial status quo and the existing European borders, as well as attain de jure recognition of the GDR. The Romanians wanted to include in the joint documents an appeal for the dissolution of the military blocs, the withdrawal of foreign troops from Europe, the elimination of foreign military bases, and the renunciation of the use of force. The East German proposals called for recognition of the GDR by the security conference.

Soviet officials indicated that to facilitate the talks the Hungarians should refrain from presenting their own proposals and wait until later to submit them. According to Moscow, the key to success was gradualism. The negotiations would have to focus on issues of economic cooperation and security, which had been favorably received by the West.

As a result of the Soviet request for Hungarian mediation on 21 October, the MSzMP Political Committee simultaneously discussed the foreign ministerial proposal and the outcome of Erdélyi's recent consultations in Moscow. ${ }^{41}$ Kádár was dissatisfied with the recommended procedure and insisted that, instead of formulating a final position at the foreign ministerial meeting, the delegations should take the proposals raised there and present them back home for debate and endorsement. Finally, after some discussion, the Hungarian leaders - as so often before-decided to accept the situation and authorize Péter to assume a "constructive" position at the upcoming meeting in accordance with Moscow's "friendly request." As a result, the Hungarian delegation played an important mediating role at the session of foreign ministers in Prague on 30-31 October 1969.

At the meeting, a vigorous debate erupted once again. When the deputy foreign ministers had met earlier to discuss various options pertaining to

40. Memorandum of conversation between Hungarian deputy foreign minister Károly Erdélyi and Soviet deputy foreign minister Semjonov on 17 October 1969 in Moscow, 18 October 1969, in MNL-OL, M-KS. 288, F. 5/501 ö.e.

41. Minutes of the MSzMP Political Committee, 21 October 1969, in MNL-OL, M-KS. 288, F./5. 501 o.e. 
the security conference, the Polish, Romanian, and East German delegates had staunchly defended their own interests. ${ }^{42}$ However, the Soviet-Hungarian gambit finally triumphed. By the end of the meeting, the parties had forged a consensus along the lines of the Soviet-Hungarian position. ${ }^{43}$ Two documents were endorsed at the session: an open declaration and a memorandum presented to Western governments. The latter document also contained the draft of the final document of the planned security conference, which revealed considerable optimism. The leaders of the Soviet bloc were similarly optimistic about the possible timing of the conference. Thereafter, at nearly all meetings, they urged that the conference be initiated within a year.

In return for cooperating in Prague, Hungarian officials were able to put forth several important proposals at this early stage that later became crucial elements of the joint Warsaw Pact policy concerning the CSCE process. Thus, the foreign ministers at their meeting in Prague agreed that a series of security conferences should take place and that a permanent organ should be set up to coordinate the preparation work. ${ }^{44}$ They also agreed that a group of experts dealing with European economic cooperation should be established within the Warsaw Pact and that its work should be coordinated by the Hungarian Foreign Ministry. This outcome underscored Hungarian leaders' desire to take the lead in promoting East-West economic relations. The assignment also showed the country's growing international status.

The main result of the foreign ministers' meeting was the Warsaw Pact states' proposal of two basic topics for discussion at the security conference: (1) European security and the renunciation of violence in relations among states; and (2) the widening of trade, economic, and technological relations based on equality, serving political cooperation among the European states. ${ }^{45}$

By the end of 1969, the formation of the Brandt government in Bonn produced a breakthrough on the question of European security. The far-reaching change in the West German position produced a distinct qualitative change, foreshadowing the possibility of the settlement of the German question, which

42. On Poland, see Jarzabek, "Hope and Reality."

43. Report to the Revolutionary Workers-Peasants Government on the meeting on 30-31 October 1969 in Prague by the representatives of the foreign ministries of the seven socialist countries, in Q1 MNL-OL, KÜM, XIX-J-1-j-VSZ-VI-003272/1969, Box 105.

44. The proposal to hold a series of conferences originally came from the Soviet side. It was raised during Semenov's talks with Péter in Budapest on 24 September 1969. The idea became a "Hungarian" initiative in the framework of the Soviet-Hungarian diplomatic game preceding the Warsaw Pact foreign ministers' meeting in Prague.

45. Foreign Ministry memorandum for the MSzMP Political Committee on the European security conference, in MNL-OL, M-KS-288, F. 5/501. ő.e. 
was of paramount importance for European security, at least from the point of view of the East Europeans. Soviet-FRG negotiations commenced on 8 December. Before long, they resulted in an agreement to hold consultations between the FRG and Poland over the recognition of the Oder-Neisse border. ${ }^{46}$

Led by a rather confused Ulbricht, a summit meeting of Warsaw Pact party leaders was held in Moscow on 3-4 December with the goal of coordinating policy vis-à-vis the FRG. ${ }^{47}$ The GDR leaders wanted to circumvent the signing of an agreement with the FRG behind their backs. Although they vehemently opposed the planned Polish-West German negotiations, a de facto PolishHungarian-Romanian "axis" emerged during the meeting seeking to push matters ahead, with support from Moscow. Thus, a majority of participants in the Moscow summit believed that the significant changes in FRG policy offered hope for settlement of the German question in concordance with the interests of the Soviet bloc. The summit resulted in a compromise: no drastic changes were allowed in the Warsaw Pact states' relations with West Germany, but they could initiate negotiations on bilateral ties with Bonn. Nonetheless, diplomatic relations could not be established until the FRG recognized the GDR in the framework of international law.

Thus, the channel for direct negotiation with the FRG was reopened after the world Communist summit in Moscow in December 1969. This was, in some sense, a move away from the Warsaw principle of February 1967, which had stated that the conditions for entering into diplomatic relations with the FRG were not yet ripe for East European countries that did not yet have such relations with West Germany.

\section{Hungary and the GDR}

For Hungary, for reasons extending beyond mere bloc discipline, the German question meant dealing with two Germanys. Hungarian-GDR bilateral relations were never especially close. In the 1960s and 1970s, apart from the Soviet Union, the GDR was the most ardent critic of Hungarian economic and domestic policy. Moreover, on some occasions GDR personnel "spied" on Hungarian internal developments and cultural life. ${ }^{48}$

46. The Soviet-FRG treaty on sanctifying the Oder-Neisse border was signed on 12 August 1970, and a similar Polish-FRG treaty was signed on 7 December 1970.

47. Report to the MSzMP Central Committee and the Hungarian government on the session of the party and state leaders of the European socialist countries in Moscow on 3-4 December 1969, 8 December 1969, in MNL-OL, M-KS-288, F. 5/507, ő.e.

48. Notes by György Aczél and Zoltán Komócsin on the activities in Hungary of an "alleged GDR" publisher, 4 February 1969, in MNL-OL, M-KS. 288, F. 5/483. ő.e. 
Serious personal conflicts occasionally erupted between the leaders of the two countries. In mid-July 1968, during the Warsaw meeting of the five Soviet-bloc states preparing for the invasion of Czechoslovakia, Ulbricht lost his composure, as he was wont to do. He not only denounced Kádár's tolerant evaluation of the situation but added that the "fraternal parties" might next have to turn their attention to resolving Hungary's internal problems. ${ }^{49}$ This implied the emergence of a dangerous tendency that entitled "fraternal parties" to act as joint troubleshooters not only in crises but also in the context of peaceful reforms. Despite posing no danger to socialism, these reforms were considered undesirable by some of the East-bloc partners-particularly the GDR. After Czechoslovakia, Hungary was the next candidate for externally imposed discipline at that time..$^{50}$

Hence, when Hungarian leaders were speaking privately among themselves, they depicted the East Germans as wholly orthodox in politics and ideology and regularly criticized them. They also regarded cynical East German tactics with great skepticism. Whereas Ulbricht acted as the Eastern bloc's chief proponent of true Marxism-Leninism, he also did everything in his power to extort as much extra profit as possible from GDR-FRG economic relations. The GDR even concealed from the other countries the true nature, magnitude, and details of the highly lucrative "intra-German business."

In public, however, Hungarian leaders vigorously supported the diplomatic struggle to secure international recognition for the GDR in the 1960s and early 1970s and avoided criticizing the East German regime. This moral support stemmed in part from solidarity based on historical experience. From the time of the revolution and Soviet invasion in late 1956 until early 1963, Hungary had fought a similar battle to escape from international isolation.

A more important motivation for Hungary's loyalty stemmed from its economic interests. Within the Eastern bloc, Hungary's most balanced economic relationship was with the GDR — a relationship that proved valuable

49. Jaromír Navrátil et al., eds., The Prague Spring 1968: A National Security Archive Documents Reader (Budapest: Central European University Press, 1998), pp. 218, 220-221. Kádár's speech is reprinted in Stefan Karner, Natalja Tomilina, and Alexander Tschubarjan, eds., Prager Frübling: Das internationale Krisenjahr 1968: Dokumente (Cologne: Böhlau Verlag, 2008), pp. 514-563.

50. This threat could in no way be dismissed as lacking credibility. A sobering precedent had been established not so long ago. Following the failure of the Hungarian revolution in 1956, the Soviet, Czechoslovak, Bulgarian, and Romanian leaders at the Communist summit on 1-4 January 1957 in Budapest forced the Hungarian party to make serious concessions concerning the political development of the country. This included vetoing the introduction of a limited pseudo-multiparty system, akin to the Czechoslovak model. The same forum also decided on the initiation of a court procedure against the members of the Imre Nagy group. Csaba Békés, Malcolm Byrne, and János M. Rainer, eds., The 1956 Hungarian Revolution: A History in Documents (Budapest: CEU Press, 2002), pp. 485-495. 
for obtaining (relatively) advanced technology at a time when export restrictions limited what could be brought in from the West. Moreover, the GDR was a reliable economic partner for Hungary, with the most developed industry among the Warsaw Pact states. East Germany gradually became a prime supplier of consumer goods that were essential for the well-being of Hungarian society, thus contributing in a substantial way to Kádár's main goal, the maintenance of a socialist consumer-oriented system. Consequently, the commercial turnover between the two states increased fourfold in the 1970s, and by the 1980s the GDR had become Hungary's third-most-important economic partner, surpassed only by the FRG and the Soviet Union. ${ }^{51}$

It is an irony of history that after decades of sustained moral support and favorable bilateral relations, a singular Hungarian diplomatic action in September 1989—namely, the opening of the Hungarian-Austrian border to East German refugees - facilitated the collapse of the East German Communist regime, ultimately leading to German unity and thus the extinction of the GDR..$^{52}$

\section{The Process of Normalization with the FRG, | 969- | 975}

Beginning in 1969, Hungarian officials devised a new approach to ties with West Germany that might be called "quasi-normalization." While patiently waiting for a general settlement of the German question - and consequently accepting the notion that Hungary might be the last Soviet-bloc country to establish diplomatic relations with the FRG-Hungarian politicians fostered dynamic improvements of Hungarian-West German economic relations at all possible levels.

In July 1969, the MSzMP Political Committee adopted a resolution that served as the basis of all future actions until early $1973 .{ }^{53}$ After the Communist summit in Moscow in December 1969, the Hungarian Foreign

51. Béla Kádár, "Magyarország gazdasági kapcsolatai az NDK-val és az NSZK-val," Külpolitika, Vol. 13, No. 1 (1986), pp. 20-21.

52. On the international context of the political transition in Hungary, see Csaba Békés, "Back to Europe: The International Context of the Political Transition in Hungary, 1988-1990," in András Bozóki, ed., The Roundtable Talks of 1989: The Genesis of Hungarian Democracy (Budapest: CEU Press, 2002), pp. 237-272. For an archive-based history of the opening of the border, see András Oplatka, Egy döntés története: Magyar határnyitás 1989 - Szeptember 11 - Nulla óra (Budapest: Helikon Kiadó, 2008).

53. Minutes of the MSzMP Political Committee, 1 July 1969. 
Ministry elaborated new guidelines for Hungarian-FRG relations, emphasizing the need to handle the issue in a flexible, tactical manner. ${ }^{54}$

This policy was aimed at killing two birds with one stone. First, the policy's highly "internationalist," loyal stance was intended to please Soviet leaders, whose goodwill and tolerance were very much needed for Hungary during the struggle to defend the economic reforms introduced in January 1968. Second, the policy was intended to be a solid overture to the FRG, which was eager to improve trade and cooperation with Hungary. From 1969 to 1973, economic relations improved in an unprecedented way. In 1970, commerce grew by 43 percent in just one year. Overall, trade between the two states tripled during this period. ${ }^{55}$ The FRG remained, as it long had, in the top place among Hungary's most important capitalist partners. Tourism also became an important source of hard currency for Hungary, and one-third of Western tourists arrived from the FRG.

The most important actions were the mutual visits of economic ministers and the signing of a five-year economic and technological agreement between the two states in 1970. These steps also facilitated the further development of "cooperation agreements" between Hungarian and West German firms. These agreements were an important means for Hungary to acquire high technology from the FRG. At that time, 65 percent of all such Hungarian contracts were made with West German firms. In the FRG itself, the majority of such contracts existed with Hungary. ${ }^{56}$ Consequently, during these years both sides felt that bilateral economic relations were in extremely good shape, with or without full diplomatic relations. ${ }^{57}$

Long-standing problems in bilateral economic ties were partly resolved at that time by the FRG's agreement to pay 100 million DM as compensation for the confiscation of assets as well as 17 million DM as compensation for forced medical treatment in Nazi concentration camps. Hungary had yet another claim against the FRG valued at more than 1 billion DM. However, officials in Budapest were under no illusions about the prospects for such restitution. Hungary, under Soviet pressure, had renounced all of these claims in the Paris

54. Foreign Ministry guidelines concerning the political and diplomatic tasks deriving from the political changes in West Germany and from the conference of the Warsaw Treaty member-states in Moscow, 20 January 1970, in MNL-OL, KÜM. XIX-J-1-j, Box 103.

55. Foreign Ministry memorandum on the Soviet bloc states with the FRG, 1971, in MNL-OL, KÜM, XIX. J-1-j, Box 78. For a survey of Hungarian-FRG relations, see Kiss, "Az első államközi megállapodástól a diplomáciai kapcsolatok felvételéig."

56. Foreign Ministry memorandum on the relations of the FRG with the socialist countries, 1971, in MNL-OL, KÜM. XIX-J-1-j, Box 78.

57. Foreign Ministry proposal on Hungarian-FRG political talks, 31 March 1972, in MNL-OL, KÜM, XIX. J-1-j, Box 78. 
Peace Treaty of 1947 . The item was kept on the agenda more as a bargaining chip than as a real demand. ${ }^{58}$

This ex lex situation was, in reality, highly favorable for Hungary. Despite achieving major progress in economic ties, Hungarian leaders were not compelled to apply reciprocity to the field of cultural relations. That is, even as Hungary was conducting an intensive cultural propaganda campaign within the FRG - often financed by West German institutions - the Hungarian government could easily and legally limit West German cultural activity by citing the lack of a cultural agreement between the two states. At the same time, Hungarian officials pursued a flexible policy toward the activity of the West German trade mission that started to behave as a quasi-legation during these years. ${ }^{59}$

A wide array of official exchanges occurred at all levels during this period, including visits from high-ranking government officials, trade union leaders, and SPD politicians. A special back-channel even evolved between the MSzMP and SPD through the services of Hans Jürgen Wischnewski of the SPD, who visited Hungary several times, mostly in secret. ${ }^{60}$

Thus, the Brandt government tacitly accepted the cautious but pragmatic position of the Hungarians. The FRG did not force the issue of establishing diplomatic relations before a general settlement of the German question. The West Germans' tolerant attitude may have been influenced by a successful intelligence operation as well. Having acquired a copy of the top secret MSzMP Political Committee resolution of 1 July 1969 on Hungarian-FRG relations, the West German government had a clear view of the Hungarians' strategy and tactics as well as of Hungarian leaders' limited room for maneuver in the Soviet bloc. ${ }^{61}$

Nevertheless, in August 1972 Brandt requested that Kádár meet with him confidentially in Bonn to discuss the establishment of diplomatic relations. ${ }^{62}$ Brandt also suggested that, as an alternative option, Wischnewski could travel

58. Foreign Ministry proposal for the forthcoming Hungarian-West German talks, 31 March 1972, in MNL-OL, KÜM. XIX-J-1-j, Box 78.

59. Report by Lothar Lahn of the West German Foreign Ministry on his conversation with Barta, head of the department for Western Europe in the Hungarian Foreign Ministry, 15 October 1970, in Akten zur Auswärtigen Politik der Bundesrepublik Deutschland: 1970 (Munich: Oldenbourg, 2001), pp. 1779-1781 (henceforth cited as AAPD with appropriate year and page nos.)

60. Wischnewski's visits were mentioned at the following meetings of the MSzMP Political Committee: 9 February 1971, 19 September 1972, 30 January 1973, 4 December 1973, 28 January 1975, and 11 November 1980.

61. Hardo Brückner, head of the West German trade mission in Budapest, to Bonn, 22 and 24 October 1969, in AAPD 1969, pp. 1151-1153, 1155-1157. This document analyzes the MSzMP resolution in detail.

62. MSzMP CC Department of Foreign Affairs proposal to the Political Committee, 30 August 1972, in MNL-OL, M-KS. 288 f. 5/590. ö.e. 
to Budapest for talks about this issue. The MSzMP Political Committee met on 5 September 1972 and decided to receive Wischnewski and inform Soviet and East German leaders about the talks. ${ }^{63}$ This happened prior to the general elections in the FRG in the fall of that year, when a diplomatic success might have raised the chances for an SPD victory.

Wischnewski, along with Eugen Selbmann, met with Zoltán Komócsin, the MSzMP Secretary responsible for international affairs, on 15 September 1972. The West Germans argued that everyone interested in the success of the détente process needed to support the SPD's bid to stay in power. The normalization of relations with Poland had provided great support to this end, and Hungary was now supposed to contribute as well by urging its partners to reconsider the issue of establishing diplomatic relations with the FRG before the forthcoming elections. Komócsin demurred, stating that Hungary had to be loyal to its allies and therefore could not establish diplomatic relations with Bonn before the normalization of West Germany's relations with the GDR and Czechoslovakia. Although support of the Brandt government was a general line of the Soviet bloc by that time, the Hungarians turned down the West German initiative. ${ }^{64}$

Consequently, a new phase of negotiations was opened only in January 1973. After the German question had been basically settled (except with respect to Czechoslovakia), the MSzMP Political Committee adopted a new resolution regarding the establishment of diplomatic relations with the FRG. ${ }^{65}$ The resolution proposed for this to happen in the first half of the year, but because of the prolongation of the FRG-Czechoslovak talks the move was postponed until the summer. After the conclusion of the Czechoslovak-FRG negotiations, Hungarian leaders expected normalization to occur in early September. By then, however, Bonn had created new problems concerning judicial assistance for West Berlin's citizens. The issue was resolved through Soviet mediation, and diplomatic relations were finally established on 21 December 1973. Prior to that, one more condition was agreed upon: Brandt confidentially requested

63. Minutes of the MSzMP Political Committee, 5 September 1972, in MNL-OL, M-KS. 288, F. 5/590. ö.e.

64. Report on Zoltán Komócsin's talks with SPD politicians H. J. Wischnewski and H. [sic] Selbmann, 15 September 1972, in MNL-OL, M-KS. 288, F. 11. cs. 3433. ő.e. For a recently published history on the MSzMP's relations with Social Democratic parties in Western Europe (especially the SPD), see István Simon, Bal-kisértés: A kádári külpolitika és a nyugati szociáldemokrácia (Budapest: Digitalbooks, 2012).

65. Minutes of the MSzMP Political Committee, 16 January 1973, in MNL-OL, M-KS. 288, F. 5/602. ő.e. 
the release of Mária Kerényi, an employee of the Hungarian Institute for International Cultural Relations, jailed for alleged spying for the FRG. ${ }^{66}$

Thus, whereas Hungary in 1967 had been among the first to respond to the prospect of reestablishing diplomatic ties with West Germany, it was the last member of the Soviet bloc actually to do so. Yet, during the years when the German question was being settled, from 1967 to 1973, Hungary enjoyed a lucrative, largely unproblematic, and even amicable relationship with West Germany.

Following normalization, the task of developing political and cultural relations remained. Economic relations were already conducted in a highly satisfactory manner. After the opening of embassies, an agreement was made concerning the establishment of a consulate general in West Berlin. In turn, the FRG was authorized to represent the citizens of West Berlin in Hungary. Political connections intensified, and in April 1974 Walter Scheel became the first West German foreign minister to visit Budapest. Both Helmut Schmidt and Kádár had been invited to each other's countries in early 1974, but the first summit was not held until 1975 at the signing of the Helsinki Final Act. Although the first visit by Kádár to the FRG was planned for 1976, it eventually took place in July 1977.

\section{Hungary, the German Question, and the CSCE Process, I 970-1975}

One major achievement of the Prague conference of Warsaw Pact foreign ministers in October 1969 was the subsequent launching of a series of intensive bilateral East-West dialogues, with active participation from the East-Central European countries. Until June 1970, Hungary held consultations with the foreign ministers of Belgium, Sweden, Netherlands, Norway, and Italy, as well as with deputy foreign ministers and heads of departments in the British, French, West German, Austrian, and Turkish foreign ministries regarding the proposed security conference. ${ }^{67}$

The CSCE process entered its most intensive phase at this time, becoming a milestone not only in Hungary's relations with the West but also in

66. Minutes of the MSzMP Political Committee, 18 December 1973, in MNL-OL, M-KS. 288, F. 5/626. ő.e.

67. Draft proposal for comrade Frigyes Puja's speech to be presented to the conference of the deputy foreign ministers of the Warsaw Pact, 19 June 1970, in MNL-OL, KUM, XIX. J-1-VSZ-1-SZU003272/1969, Box 105. 
Hungarian-Soviet relations. By 1969, a special Soviet-Hungarian partnership mechanism had evolved. Hungary proved to be an ideal partner for Moscow in this complex process-a process in which convincing allies was often more difficult than persuading the other side.

Subsequently, a far-reaching shift occurred in Hungarian foreign policymaking. The old model remained formally unchanged. Notably, every important issue at the decision-making level remained in the hands of the MSzMP Political Committee. However, major changes were introduced in preliminary decision-making, initiation, proposals, implementation, and auxiliary diplomatic work. The role of the Foreign Ministry apparatus increased significantly, and the intensity of multifaceted and multidirectional negotiations assumed an important role alongside the Political Committee. Presumably, this became the starting point for the emancipation of Hungarian foreign policy activity. Although this process had commenced as early as 1963, the fundamental shift toward the active and intensive role of Hungarian diplomats occurred during the CSCE process.

From this time on, the European security conference became a high priority for Hungarian leaders, who had been intensely pursuing economic opportunities vis-à-vis the West since the mid-1960s. Aside from Romania and perhaps Poland, Hungary was likely to gain the greatest benefits from the process in light of the positive effects it was expected to have on the evolution of East-West relations. Hungarian leaders assumed correctly that these objectives had to be pursued within the framework of a divided Warsaw Pact. Hence, they deduced that for the sake of success, more effective and more systematic coordination of foreign policy was necessary within the Soviet bloc. In this respect, the establishment of the Pact's Council of Foreign Ministers (CFM) - proposed by Hungarian leaders on several occasions from 1958 on-might have served as a suitable platform. ${ }^{68}$ The Hungarians knew that Romania opposed the establishment of the CFM, but they hoped that "Leninist gradualism" would prevail in this respect, too, so that even if an official body (the CFM) were not created, perhaps a regular platform of foreign ministers could surface. During a visit to Moscow in December 1969, Foreign Minister Péter proposed this idea to Gromyko. Soviet leaders quickly approved it and authorized the Hungarians to start preparations for the

68. See Csaba Békés, "Titkos válságkezeléstől a politikai koordinációig: Politikai egyeztetési mechanizmus a Varsói Szerződésben: 1954-1967,” in János M. Rainer, ed., Múlt századi hétköznapok: Tanulmányok a Kádár rendszer kialakulásának idöszakáról (Budapest: 1956-os Intézet, 2003), pp. 9-54. 
necessary bilateral consultative negotiations. ${ }^{69}$ In January 1970, Deputy Foreign Minister Frigyes Puja paid a visit to Bucharest to discuss the plan, but the mission failed. The Romanians did not accept the creation of the CFM until 1974 , under changed conditions. The body was finally established in $1976 .^{70}$

In early 1970, auspicious developments in international politics bolstered the chances of staging a security conference. In a speech to the U.S. Congress on 18 February, Nixon declared that the United States recognized the Soviet Union's legitimate security interests in Eastern Europe and stressed his willingness to negotiate in the interest of reducing international tension and promoting rapprochement. The resolution adopted by the North Atlantic Treaty Organization (NATO) at its meeting in Rome on 26-27 May 1970 contained numerous new elements. Most notably, it mentioned the security conference in concrete terms and proposed to stage multilateral negotiations under certain conditions. The NATO declaration did not link the issue of troop reductions in Europe with CSCE.

Following these developments, the real turning point concerning the plans for a European security conference came at the June 1970 meeting of the Warsaw Pact foreign ministers in Budapest, convened at Hungary's initiative. This event marked the end of exploratory negotiations and the beginning of the period involving direct East-West dialogue over the staging of a European security conference. A dynamic debate ensued among the participants at the meeting, as well as at the preceding deputy foreign ministers' session, and the Hungarian hosts played at least as intensive a mediating role as they did during the formulation of the Budapest Appeal. ${ }^{71}$

The conference became the second major turning point in the CSCE process within the Warsaw Pact (the first being the Budapest Appeal), primarily because the Pact now adopted two conditions demanded by the Western side to allow preparatory negotiations to proceed. First, the Pact's declaration recognized the right of the United States and Canada to participate in the conference as full members. Second, apart from the two points on the agenda proposed by the Warsaw Pact, the declaration acknowledge that a third point

69. Report to the MSzMP CC and the government on the foreign minister's official visit to the Soviet Union, 22-29 December 1969, 6 January 1970, in MNL-OL, KÜM, XIX. J-1-j-SU-00949-1/1970, Box 80 .

70. On the Warsaw Pact CFM, see Anna Locher, Shaping the Policies of the Alliance: The Committee of Ministers of Foreign Affairs of the Warsaw Pact: 1976-1990 (Zurich: Parallel History Project on NATO and the Warsaw Pact, 2002).

71. Report to the Revolutionary Workers-Peasants Government on the 21-22 June 1970 conference of Warsaw Pact foreign ministers in Budapest, 29 June 1970, in MNL-OL, KÜM, XIX. J-1-j-EU2008-00482/20/1970, Box 93. 
should be included: the issue of cultural relations and the investigation of the human environment. Although the Soviet Union and other Warsaw Pact member-states had been well aware that staging the conference would be impossible without the United States and Canada, they raised this matter for tactical reasons until they managed to secure the participation of the GDR in exchange. The topic of cultural relations was adopted via a Hungarian initiative, which meant no less than the tacit incorporation of the "third basket" (as it was named in a later phase of the preliminary dialogue) in the structure of the multilateral talks. The question of the third basket played a key role at a later stage insofar as it contained the components that mirrored basic Western interests during the great European settlement. This factor served as a foundation for the evolution of the human rights campaign of the postHelsinki period, which eventually played a limited role in the disintegration of the East-Central European Communist systems at the end of the 1980s.

A decision was also reached at the foreign ministers' meeting in Budapest regarding the establishment of a permanent body that would assume responsibility for issues related to European security and cooperation, particularly to assess options for the reduction of the armed forces. The Soviet Union agreed to hold talks on reductions of European armed forces in parallel with negotiations on European security. The talks were ostensibly a confidence-building measure, though in fact they were intended mostly to deflate the significance of a NATO proposal of similar content formulated at the time. Furthermore, the foreign ministers sent a draft document to Western governments outlining proposals for economic, technological-scientific, and cultural cooperation. Helsinki was accepted as the venue for the conference. Thereafter, the procedure empowering accredited ambassadors to carry out preparatory work in the Finnish capital became an official proposition.

Last but not least, the Warsaw Pact foreign ministers reiterated at their meeting in Budapest that the convening of a European security conference had no preconditions. This was highly significant insofar as Poland, East Germany, and Czechoslovakia had earlier hoped that the Soviet bloc would require settlement of the German question as a specific precondition. The pressure from these countries would have hindered and delayed the process. However, close cooperation between Soviet and Hungarian officials, coupled with de facto support from the Romanians, succeeded in circumventing this possibility.

The conclusion of the Soviet-West German treaty in August 1970 was a major breakthrough in the struggle to resolve the German issue. After the treaty was signed, a session of the Warsaw Pact PCC was urgently convened in Moscow. The only thing that cast a shadow over the breakthrough was Nicolae 
Ceauşescu's proposal suggesting that the time had come for Czechoslovakia, Bulgaria, Poland, and Hungary to establish diplomatic relations with the FRG. The proposal was rejected by the others, including Kádár, who stuck by the timetable worked out by the Warsaw Pact in December 1969. This attitude raised some worries in Budapest, where some members of the MSzMP Political Committee suggested that Hungary should perhaps have seized this opportunity to settle relations with West Germany. ${ }^{72}$

The next PCC session, held at the beginning of December 1970 in East Berlin, was unusual. Meetings at the highest level were held irregularly, and two in one year was extraordinary. Partly this was because a few days later, the Polish-FRG treaty was also signed, another significant success on the road to settling the German issue. At the PCC meeting in East Berlin, the Polish-West German deal was discussed. After the Polish-FRG treaty was ratified, the Poles were given permission to enter into diplomatic relations with the FRG as the first of the four hold-out Warsaw Pact states. ${ }^{73}$

Strangely enough, the Warsaw diktat prepared in February 1967 was now set aside by Poland, one of its coauthors, even though only one of the six points of the secret Warsaw protocol had been met. The official explanation communicated to the other Warsaw Pact countries was that the Brandt cabinet, being in a difficult position and attacked by the United States over Ostpolitik, badly needed to show progress. Kádár had learned unofficially that the FRG had set this as a precondition for signing the treaty.

This new approach, whose flexibility deviated from earlier principles, was now accepted by the leaders of the GDR as well, even though East German leaders had been vehemently opposed to even the planned commencement of negotiations between Poland and the FRG a year before. However, the timetable for the three other Soviet-bloc countries that did not yet have diplomatic relations with the FRG was reaffirmed. They could normalize their relations only if the two treaties were ratified, if West German-East German relations were normalized (including recognition of the GDR in accordance with international law), and if the FRG acknowledged that the Munich agreement had been invalid from the start.

At the meeting, Brezhnev stressed the need for regular consultations, particularly during preparations for the European security meeting. Therefore, he proposed that a CFM be established within the Warsaw Pact. Everyone

72. Minutes of the MSzMP Political Committee, 25 August 1970, in MNL-OL, M-KS. 288, F. 5. cs. 525. o.e.

73. Minutes of the MSzMP Political Committee, 8 December 1970, in MNL-OL, M-KS. 288, F. 5. cs. 538. ő.e. 
except Ceauşescu endorsed the proposal. Kádár strongly endorsed it, not least because he was the one who had originally raised it during Hungarian-Soviet bilateral talks. Moreover, Hungarian officials had made considerable efforts at the beginning of 1970 to establish this consultative body. However, because Kádár expected a veto by the Romanians, he also suggested a more flexible solution and proposed that, if the new body could not be established now, an agreement should be made requiring foreign ministers or their deputies to meet more frequently in the future for the purpose of conducting consultations. ${ }^{74}$

In July 1971, after the conference of "European nations" fostered the allEuropean security conference held in Brussels by Soviet initiative, Hungarian leaders also took further steps to promote the idea of the European security conference. The MSzMP Political Committee adopted a resolution to set up the Hungarian National Committee of the Conference on Security and Cooperation in Europe. The 42 members of the committee were public figures, scholars, journalists, writers, actors, trade unionists, and church leaders, as well as ordinary people (e.g., members of cooperative farms). The large size of the body did not cause any operational concerns inasmuch as Kádár clearly stated that "an individual will never do anything on his own. They will meet once or twice." 75

The foreign ministers of the Warsaw Pact had another session in Warsaw from 30 November to 1 December 1971. The main goal was to accelerate preparations for the European security conference. In the communiqué issued about the conference, all the participating countries were urged to take practical steps to allow the conference to begin as early as 1972. In his speech, Hungarian Foreign Minister Péter responded to the well-known Romanian position that the conference must not entail negotiations between the two blocs. Wanting to mediate the different positions within the Warsaw Pact, Péter stressed the need for multiple levels of negotiation: first, there was a need for continual negotiation within the blocs insofar as "even within each bloc and military organization not every member can understand the goals of the security conference or they do not evaluate it in the same way"; second, coordination was required between the blocs; third, the blocs needed to coordinate preparatory work that involved states outside the blocs insofar as "every affected country should take part in this work, and the main goal is to build the issue of security on autonomous and independent states rather

74. See Csaba Békés, Anna Locher, and Christian Nuenlist, eds., The Records of the Warsaw Pact Deputy Foreign Ministers (Zurich: Parallel History Project on NATO and the Warsaw Pact, 2005.)

75. Minutes of the MSzMP Political Committee, 13 July 1971, in MNL-OL, M-KS. 288, F. 5. cs. 559. o.e. 
than on blocs. ${ }^{176}$ Péter urged additional consultations within the Warsaw Pact, especially on the topic of European economic cooperation, suggesting that the first meeting held in Budapest should be followed by a second meeting in Warsaw. ${ }^{77}$

The next important stage in the process of political coordination (which was rapidly increasing in intensity) within the Warsaw Pact was the Warsaw Pact PCC session held in Prague in January 1972. The conference produced a statement calling for the European Conference on Security and Cooperation to be convened as soon as possible. They accepted the Finnish proposal to begin preparatory talks at the level of ambassadors, announced they would nominate representatives, and called on the other European countries to do the same. They also called on the U.S. and Canadian governments to begin practical preparations so that multilateral preparatory talks could begin in 1972 . The announcement failed to mention that the major issue of the conference would be the shaping of future relations with the FRG.

Although the timetable that had been in existence since the Warsaw diktat (and was later made more precise in December 1969) was softened at the Moscow PCC session held in August 1970, the participants at that time unanimously adopted it alongside the modifications made in Moscow. However, now that the ratification of the two treaties was clearly within reach, fighting flared up again among the participants, who sought to bolster their own interests. The available sources reveal five distinct positions - a number nearly equal to the number of participants. ${ }^{78}$

1. East German position: diplomatic relations should be established only if the GDR is admitted to the UN.

2. Czechoslovakian and Soviet position: diplomatic relations should be established only after the FRG had recognized that the Munich agreement had been invalid since its inception.

3. Polish position: sometime after the ratification, Poland alone would enter into diplomatic relations with the FRG but would coordinate this step with the others.

76. Minutes of the MSzMP Political Committee, 14 December 1971, in MNL-OL, M-KS. 288, F. 5. cs. 570 . ő.e.

77. On the Polish position, see Wanda Jarzabek, "Hope and Reality: Poland and the CSCE: 19641989."

78. Record on the Warsaw Pact PCC meeting on 25-26 January 1972 in Prague, in MNL-OL, M-KS 288, F. 5. cs. 573. o.e. 
4. Hungarian position: after the ratification of the treaties, new negotiations should be conducted: Poland, Hungary, and Bulgaria should settle their relations with Bonn.

5. Romanian position: the four other countries should enter into diplomatic relations with the FRG now.

Apparently emboldened by the developments and relying on the support of the PCC, the GDR submitted another extreme demand that had not been raised before even as an option: namely, that Czechoslovakia, Poland, Hungary, and Bulgaria should not enter into diplomatic relations until the GDR had been admitted to the UN.

The Czechoslovak position (shared by the Soviet Union) was that diplomatic relations should be established only if the FRG recognized that the Munich agreement had been invalid since its inception. They took this position even though Czechoslovak Communist Party First Secretary Gustáv Husák acknowledged that the situation was likely hopeless and that reaching such an agreement would likely take a long time. Nonetheless, he suggested that the PCC (and, first of all, the Soviet Union) make an attempt by putting political pressure on the FRG. His request that this condition be included in the PCC statement was accepted.

The Polish position - that sometime after ratification Poland alone would enter into diplomatic relations with the FRG but would coordinate this step with the others-was so ambiguous that clarifying what it meant is problematic even now. Apparently, Edward Gierek deliberately discussed the resolution of the German issue in vague terms, arguing that although the Poles endorsed setting invalidation of the Munich agreement as a precondition for normalizing relations, the FRG's recognition of the GDR in accordance with international law would mean the end of normalizing relations with the FRG. Gierek's speech suggests that such a step, despite not being included as one of the preconditions, would be the endpoint of the normalization process.

No wonder Kádár had a hard time interpreting the Polish position when presenting his report to the MSzMP Political Committee. ${ }^{79}$ The Hungarian notes from the PCC session went as far as to interpret the Polish speech as a step backward, as abandoning the Poles' earlier promise to the FRG that they would establish diplomatic relations after ratification. ${ }^{80}$ However, toward the end of the Political Committee meeting, Kádár became engaged in a lengthy

79. Report by János Kádár at the MSzMP Political Committee meeting, 1 February 1972, in MNLOL, M-KS. 288, F. 5. cs. 573. o.e.

80. Record of the Warsaw Pact PCC meeting, 25-26 January 1972 in Prague. 
exposition. He repeated Gierek's statement made at the PCC session that Poland would enter into diplomatic relations with the FRG and coordinate this step with the other member-states.

The greatest surprise at the Warsaw Pact PCC meeting in Prague in January 1972 was produced by Kádár when he argued that new negotiations should be conducted after the ratification of the treaties. The Hungarian leader up to that point had been loyal to the Warsaw Pact timetable and had refrained from modifying the plan through either bilateral or multilateral channels. Kádár was probably improvising at the PCC session, for he had no authorization from the MSzMP Political Committee to submit a new proposal. Perceiving the nearly anarchic situation and the selfishness of the "fraternal" countries, he was probably angry that the others abused Hungary's loyal goodwill. He likely aimed to delay any chances for Hungary to settle its relations with the FRG by imposing conditions that clearly could not be fulfilled in the short term. Sensing that discipline within the bloc had loosened, Kádár believed this was a great opportunity to test whether the timetable could be modified to the benefit of Hungary. Reporting to the Warsaw Pact PCC after the MSzMP Political Committee met, he said: "We were in a phase of the discussion in which the Poles said that if the treaties are ratified, they will enter into diplomatic relations. And it was no coincidence that we hooked the two other carriages on to this. The Poles have a seriously disputed issue, but they will resolve it by the ratification; the Bulgarians do not have any, and there is no reason to wait." ${ }^{11}$

Kádár told the PCC that immediately after ratification-that is, before the Czechoslovak-FRG agreement was reached and the GDR was recognized by Bonn-another consultative PCC meeting should be held to decide about relations between Bulgaria, Poland, Hungary, and the FRG. He stressed that the dispute about the Munich agreement would last quite long but that something should be offered to the FRG in return for ratification. The possibility that Kádár had another, secret motive in this fluid situation is reflected in a mysterious comment he made about the Munich agreement in his report on the PCC meeting to the MSzMP Political Committee: "This is not easy from the Hungarian perspective, either. The annulment of the Munich agreement also affects Hungary. However, nobody mentions this fact; people just forget about it." ${ }^{82}$ After the Munich agreement, the First Vienna Award established by the German-Italian Arbitral Tribunal in 1938 had awarded the territories of

81. Report by János Kádár at the MSzMP Political Committee meeting, 1 February 1972.

82. Ibid. 
southern Slovakia (mostly populated by Hungarians) to Hungary-territories that had been separated from Hungary by the Trianon peace treaty after World War I. Kádár drew a logical parallel between the arguments of the FRG (the award of the Sudeten region to Germany in accordance with the ethnic principle) and the Hungarian situation. Thus, Hungary's endorsement of the Czechoslovak position also meant permanently surrendering any Hungarian territorial claims against Czechoslovakia. Although Hungarian leaders never raised the matter openly, the final surrender of the territories populated by Hungarians was no less a trauma for them than for the Germans, who had to reconcile their losses of the Polish and Sudeten-German territories. This is especially true because the Germans were expelled from these territories after World War II, whereas Hungarians had continued to live in Slovakia.

Kádár was apparently at his best during the Warsaw Pact PCC conference in Prague. In sharp contrast to his earlier, defensive attitude, he put forward a "Plan B" to resolve the issue in a favorable way. Emphasizing how important it was for NATO member-states to recognize the GDR as soon as possible, he cited the example of France, noting that during recent negotiations in Budapest the French foreign minister had suggested that France would be willing to recognize the GDR if Hungary, in return, established diplomatic relations with the FRG.

In preparation for CSCE, Kádár proposed that a new large-scale campaign be launched to persuade West European countries to accept a start date in 1972. He called for the PCC to back Finland's initiative to hold a conference for ambassadors in Helsinki that would prepare for the conference. The ambassadors or special envoys of the Warsaw Pact states in Helsinki, he said, should contact the Finnish government on the issue of multilateral consultation. The Warsaw Pact countries themselves should ensure that they had a coordinated, well-established position on every important issue of the security conference, including who would represent them at the preparatory talks and the security conference itself. In addition, they should propose an agenda for the conference, taking into consideration any acceptable proposal submitted by Western countries, and should formulate a position on military and military-political issues concerning the reduction of arms and troops.

Kádár claimed that further intensive work was needed to elaborate proposals concerning European economic, trade, scientific, technological, and cultural cooperation. The concrete issues of cooperation relating to the protection of the human environment needed to be addressed. He also warned that the NATO countries should be prevented from playing the leading role in issues pertaining to the exchange of information and increases in tourism. He stressed that special attention should be devoted to the involvement of 
social organizations that could promote the idea of the security conference by focusing on, for example, cooperation between Eastern and Western trade union organizations. In this context, Kádár also mentioned that the conference convened in Budapest in the fall of 1972 for European mayors would be an important event.

After the Warsaw Pact PCC conference in Prague, the preparatory work on the CSCE gathered considerable speed within the Warsaw Pact. From the beginning, Hungarian leaders attached considerable importance to the issue of European economic cooperation, the field in which Hungary could expect the most from a successful conference. Accordingly, as early as April 1970, economic experts held a conference in Budapest. In October 1971, a detailed summary, prepared on the basis of previous intra-bloc consultations, was sent to all member-states of the Warsaw Pact. In February 1972, a 26page guideline was prepared under the title "The Prospects of Pan-European Economic Cooperation." One of the most important suggestions was the establishment of the European Economic Committee as the body responsible for European economic cooperation after its proper transformation. ${ }^{83}$ This proposal was especially remarkable because the authors of the document were fully aware that the Soviet Union opposed assigning this body a key role after the conference.

Puja, the first deputy foreign minister, made several proposals during his visit to Moscow in March 1972 to speed up work. He proposed to arrange a Warsaw Pact consultation as soon as possible in order to set up specialist working groups to address the issues of the free flow of information and the free movement of people. Furthermore, the documents adopted at the meeting of foreign ministers in October 1969 in Prague and in June 1970 in Budapest regarding the objectives and the agenda of the security conference had become outdated. A new proposal was needed, and Puja urged the leaders to resume consultations on economic cooperation that had begun earlier in Budapest and for the Soviet Union to take a position on this topic. As he explained, this was urgent because the Hungarian party needed a chance to expound the position of the Warsaw Pact on this issue while intensive negotiations with the Western countries were being conducted..$^{84}$

83. "The Prospects of Pan-European Economic Cooperation," Proposal for the Committee of International Economic Relations, 24 February 1972, in MNL-OL, KÜM. XIX-J-1-j-EU-208-IX-00709/11972, Box 12.

84. Memorandum for the forthcoming consultations of Frigyes Puja in Moscow, 17 February 1972, in MNL-OL, KÜM. XIX-J-1-j-SzU-144-001190/14/1972, Box 95. 
The Hungarian Foreign Ministry was also working intensively on the preparations for the CSCE throughout 1972. In the summer of that year, the idea was raised that if insufficient progress was being made in preparing for the conference (notably if Western countries were playing for time), Hungary should issue a unilateral memorandum and try to make progress by publishing the results of Hungarian diplomacy talks conducted with the Western countries up to that time. ${ }^{85}$

At the Crimean meeting of the Warsaw Pact countries on 31 July 1972, Brezhnev took great pains to forestall the turbulence that had characterized the January PCC session in Prague on the German issue. He argued that the FRG after ratifying the two treaties would make additional concessions only by means of concerted and uniform action. Therefore, with a view to preventing any serious dispute, he made clear: "If all the socialist countries were to enter into diplomatic relations with the FRG in the near future, that would practically mean weakening or even losing one of the most important tools of influencing Bonn's policy. This step would further complicate the position of our German comrades at the talks being conducted with the FRG at present." Brezhnev's remarks could be interpreted as withdrawing the special permission that had earlier been granted to the Poles. ${ }^{86}$ On the other hand, his wording did not actually preclude the option of another Soviet-Polish special deal, especially since Poland eventually did enter into diplomatic relations with the FRG in the fall of 1972.

Brezhnev's warning was, above all, addressed to Kádár, who proposed at the Warsaw Pact PCC meeting in Prague that, after the ratification of the two treaties, Poland, Hungary, and Bulgaria should jointly enter into relations with the FRG. Kádár never engaged in any open confrontation with the Soviet Union at multilateral fora. Thus - seeing that his original proposal would never find support at this forum—he found another trick. Seeing that Brezhnev made Poland retreat as well, Kádár seemed to side with Brezhnev, stating that joint action was needed against the FRG in the months to come because "four beats three" and, "if we remain fewer, the result will not be the same." At the same time, in an attempt to convince the FRG to accept the demands of the Warsaw Pact by joining their forces, he urged that the deadline be before 22 November, the date when the multilateral East-West preparatory talks in Helsinki were to begin. In particular, he suggested that the

85. Tasks concerning the preparations for the European security conference, 2 June 1972, in MNLOL, KUM. XIX-J-1-j-EU-208-IX-00607-1972, Box 12.

86. Report by János Kádár at the MSzMP CC session on 2 August 1972, in MNL-OL, M-KS. 288, F. 4/42. ô.e. 
Poles should claim they were entering into diplomatic relations as promised but that they should play for time as long as possible. Kádár's challenge to Poland's privileged position should be viewed in light of the Warsaw diktat imposed on Hungary by Poland and the GDR in February 1967.

Kádár also advised the Czechoslovak and East German authorities on the matter. He suggested that they should not make any far-reaching concessions at the talks but should nonetheless seek other ways to help settle relations, notably by being more flexible. However, he firmly refused Erich Honecker's idea to make UN membership of the GDR a precondition for settling relations between the FRG and the other socialist countries.

Concerning the general international situation, Kádár expressly stated that whatever happened in the FRG-that is, even if the opposition were to win the early elections - the results already achieved could not be undone, and the Eastern policy of the FRG would stay in place even if the SPD were defeated. This was especially important, for although Brezhnev was essentially just as optimistic about the situation, he did not exclude the possibility of restoration, which in his view would mean returning to the Cold War.

At the Crimean meeting, Kádár called attention to another problem: an agreement by the two Koreas to reunify peacefully could pose a serious problem in the European context. Enforcement of the principle of "two political systems in one country" could not be regarded as a Marxist solution, because "if it was translated into the German language, Comrade Honecker would perhaps not subscribe to it, but Barzel or Brandt would promptly sign such an agreement." ${ }^{\text {77 }}$

Over the summer of 1972, preparation for the security conference gained momentum in the Soviet Union too. That was when the special political reconciliatory reforms that had fundamentally characterized the CSCE process were beginning to emerge. By excluding the Romanian factor, the reforms tried to resolve the issue of multilateral consultations. One such method (often suggested by Moscow) stressed the need to conduct bilateral negotiations concurrently. In this spirit, Nikolai Sikachev, head of department at the Soviet Ministry of Foreign Affairs, handed over three documents to the Hungarian Foreign Ministry during his visit to Budapest on 24-25 August. They were in turn sent to the "closely cooperating" sister parties (i.e., the Warsaw Pact states, excluding Romania) for their opinion. ${ }^{88}$

The documents included the following: the draft version of the final communiqué of the conference preparing the Helsinki conference; a document

87. Report by János Kádár at the MSzMP Political Committee meeting, 2 August 1972, in MNL-OL, M-KS. 288, F. 5. cs. 587. o.e.

88. Minutes of the MSzMP Political Committee, 5 September 1972, F. 
entitled "General Statement on the Fundamentals of European Security and the Principles Governing the Relations among European States"; and a resolution on establishing a consultative committee. At a session on 25 September 1972, the MSzMP Political Committee discussed these documents, accepted the drafts, and proposed to add the following to the general statement:

1. The section on economic cooperation among the European states was to be supplemented with a statement that efforts should be made, in the framework of cooperation, to work out a joint solution attending to the economic tasks affecting all European countries. Such issues would include: stopping the shortage of energy, coupling energy systems, linking European water routes, and so forth.

2. The issues relating to cultural cooperation were to be presented in a positive way that would stress Hungarian readiness for multilateral cooperation, thus anticipating and neutralizing the Western demand for "the free flow of people, ideas and information."

3. The introductory section would touch upon the need for disarmament; the statement section should also include the issue of reducing foreign and national troops stationed in Europe. The statement should refer to separate talks to be conducted on this issue. Such a reference was likely to satisfy the neutral and NATO countries and make the prospect of cooperation with Soviet-bloc countries more acceptable.

4. The statement should make reference to the results already achieved by the European countries in consolidating European security. Mention could also be made of the Soviet-FRG treaty, the Four Powers agreement on West Berlin, the agreements between the Soviet Union and France and the Soviet Union and the U.S. on cooperation, as well as the negotiations conducted by the two German states. ${ }^{89}$

Just before the multilateral preparatory talks in Helsinki, a consultative meeting took place in Moscow on 15 November 1972 for the deputy foreign ministers of the Warsaw Pact. Nagy attended on behalf of Hungary, submitting three tactical proposals. First, if the West insisted, the Warsaw Pact should agree to include environmental issues as a separate item on the agenda. Next, although the Warsaw Pact should initially firmly reject the matter of the "free

89. Ibid. 
flow of ideas," a short general sentence might be added to the title of the second item on the agenda in case the Western countries tried to use this point as an excuse to drag out the conference. Finally, there was to be a rational division of labor among the socialist delegations at the meetings.

From 27 November to 1 December 1972, a Soviet state and party delegation conducted negotiations in Hungary. During talks with Brezhnev, Kádár again raised the issue of diplomatic relations with the FRG, demonstrating considerable "flexibility" by now saying that he believed Poland had made the right decision in establishing diplomatic relations with Bonn. ${ }^{90}$ With a view to the Czechoslovakian-FRG talks, he again tried to assert that Hungary should not have to wait until the end of this process: "It is not a good idea to drag out the establishment of Hungarian-West German diplomatic relations too much, because such a step might produce just the contrary effect." ${ }^{11}$

Brezhnev did not respond to the suggestion but caught his hosts by surprise when he delivered a general analysis of the international situation. Despite the results achieved in détente, Brezhnev emphatically stated that

Great attention should be devoted to increasing the defensive power of the Warsaw Treaty. The defensive capability of the national military forces of the European socialist countries must be increased and provided with modern military technology, since there is a clear shortfall in this respect. The defense of the homeland is the number one issue in the Soviet Union, and accordingly it has priority over anything else when deciding on the allocation of financial resources. $^{92}$

Although the talks on reducing troops in Central Europe-projected to begin in Vienna a month later-were mentioned only in a general context at the meeting, Kádár had no doubt, after hearing Brezhnev's comments, that the Soviet Union would not take any real steps to reduce armaments. Brezhnev also promised that the Warsaw Pact PCC would soon convene to discuss the international situation, as urged by Kádár since the beginning of the year; but, as it turned out, the session was not held until April 1974.

At the next meeting of foreign ministers in Moscow in January 1973, the ministers discussed issues relating to Central European arms reduction negotiations and their joint policy concerning the preparation for the European security conference in Helsinki. The most important development regarding

90. Report by János Kádár at the MSzMP Political Committee meeting, 5 December 1972, in MNLOL, M-KS. 288, F. 5. cs. 599. o.e.

91. Ibid.

92. Ibid. 
the Helsinki talks was that the foreign ministers agreed to split the second item on the agenda into two: the first would focus on trade, economic, and scientific/technological relations; and the second would be concerned with cultural cooperation, relations between people and organizations, and widening the scope of information dissemination. ${ }^{93}$ The modification took place under the pressure exercised by the Western countries, and the Warsaw Pact memberstates hoped that in this way they could prevent the topic of the free flow of ideas from becoming a fully separate item on the agenda. Their attempt was a failure, leaving them with no option but to accept the third basket.

At the meeting, Péter stressed the importance of unified, concerted action by the socialist countries, arguing that many more intensive bilateral and multilateral consultations would be required in the future because new issues regarding the European security conference kept emerging. ${ }^{94}$ Furthermore, he warned that the Warsaw Pact states should continue to take the initiative, or else the Western countries might gain the initiative for themselves.

The ministers worked out a joint position regarding the arms reduction talks. The key element was that every European state that showed interest in the issue should be given a chance to participate both in the preparatory talks and the actual negotiations. The states designated for arms reduction this time around had not yet been identified, so the ministers did not mention that Hungary_clearly a Central European country in the geographical sensewould not participate in the reduction of arms. This issue was critical for some time at the preparatory talks beginning in Vienna at the end of January 1973. In principle, the Western countries had every reason to expect that one of the most centrally located countries of the region would be part of the plan. (That Hungary - together with Romania and Bulgaria — belonged, militarily and strategically, to the southern wing of the Warsaw Pact is quite another matter.) Therefore, the Western states were especially concerned about the announcement that, of all the socialist countries, only the Soviet Union, the GDR, Poland, and Czechoslovakia would participate in the arms reduction. Hungary would be included only if Italy were also included in the plan. The NATO states feared that under this solution the Soviet troops stationed in Czechoslovakia would simply be redeployed on Hungarian territory and there, in effect, would not be withdrawn from the region.

93. Foreign Ministry report on the conference of the Warsaw Treaty foreign ministers on 15-16 January 1973 in Moscow, 23 January 1973, in MNL-OL, KÜM, XIX-J-1-j-VI-1-00455/7-1973, Box 128.

94. Ibid. 
This solution presented Hungarian leaders with a serious dilemma. Because Soviet leaders were resolute on this issue, the Hungarians held out little hope that Moscow could be swayed if the issue of Hungarian participation were raised. In addition, Hungarian leaders had already been engaged in a serious dispute with Brezhnev since the beginning of 1972. Their economic reforms and developments in domestic polity had evoked severe criticism from Soviet officials, who perceived Hungarian economic policies as developing toward capitalism. Furthermore, in December 1972 Kádár learned from Brezhnev that he had no reason to expect any results from the arms reduction talks, at least not in the short run, and that these negotiations were necessary only to ensure the success of the European security conference.

Kádár himself had been confronted with a similar dilemma before. In 1958, Khrushchev had suggested that Soviet troops might pull out of Hungary concurrently with the withdrawal of Soviet troops from Romania. At that time, Kádár thought the move would be premature and would jeopardize his efforts to consolidate an internal situation that was still unstable in the wake of the 1956 revolution. He thus rejected the offer. ${ }^{95}$ The offer itself was kept secret so that Hungarians would not be angry at Kádár for his rejection of it. By 1973, however, the situation was quite different. After 15 November 1972 the proposal set out in the NATO note regarding the inclusion of Hungary became widely known. Thus, Hungarian leaders faced the difficult task of explaining to the public why they were not interested in reducing military expenditures or in a partial withdrawal of Soviet troops.

During the preparatory talks in Helsinki, Hungary-using "constructive loyalty," the key principle of Hungarian foreign policy-actively participated in the work, constantly negotiating with the USSR and other Warsaw Pact member-states. Using a policy contrary to that of the Romanians, the Hungarians did not aim for any spectacular action and instead tried to mediate between the two camps in a quiet, flexible way. They made efforts to popularize the position of the Warsaw Pact at the talks conducted with the Western countries. Meanwhile, within the Eastern bloc they tried their best to sell any reasonable Western proposal that seemed acceptable. Accordingly, at the conference held in Moscow on 21-22 May 1973 among the Warsaw Pact deputy foreign ministers, Puja stressed that serious disputes should be expected from the talks in Helsinki but that there was nothing to be gained by focusing on those disputes. Instead, he suggested that the socialist countries continue to

95. See Békés, “Titkos válságkezeléstől a politikai koordinációig," pp. 24-25. 
hold bilateral talks with EC and neutral countries, because that was the best way to influence those countries' position.

Before the first phase of CSCE that began in July 1973 in Helsinki, the MSzMP and the Hungarian government adopted guidelines for the speech to be given by Foreign Minister Péter. Besides general statements about Hungary's interest in easing tensions in international relations and increasing international cooperation, Péter's speech stressed that the establishment of a consultative body would be especially important for economic and cultural cooperation. As far as economic cooperation was concerned, the speech called for the elimination of trade discrimination and argued that the elaboration and implementation of plans requiring European collaboration played a key role in raising the living standard of European countries. The speech also emphasized that industrial cooperation between countries from opposing political systems, and not just trade relations, provided a more secure guarantee against new tensions. The relevant experience Hungary had gained in this area had to be presented to the conference.

As for the third item on the agenda, Péter's speech emphasized the cultural and educational relations portion of the topic in order to prove that the culture of the socialist countries and the results they had achieved in educating young people could present countries of an opposing political system with useful experience.

Echoing the general optimism in the Soviet bloc after the Geneva summit in July 1955, Hungary asserted that every remnant of the Cold War must be eradicated from the relations between countries. As for human relations, Hungarian data on the experience of the Soviet-bloc countries "supported the expansion of relations between people and organizations in every respect and [showed that such expansion] had always played a key role in easing cold war tensions." $"$ 6

Eventually, the next conference of the Warsaw Pact PCC was convened until April 1974 in Moscow-despite Brezhnev's repeated promise that it would take place as early as 1972. Joining Brezhnev's position, Kádár at the meeting stated with satisfaction that the socialist countries through their joint action had practically achieved everything they had wanted in resolving the German issue. ${ }^{97} \mathrm{He}$ explained that a decisive turn for détente had taken place in the international situation and expressed his conviction that peaceful

96. Minutes of the MSzMP Political Committee, 19 June 1973, in MNL-OL, M-KS. 288, F. 5. cs. 613. o.e.

97. Report by János Kádár at the MSzMP Political Committee meeting, 23 April 1974, in MNL-OL, M-KS. 288, F. 5. cs. 635. o.e. 
coexistence was a historically inevitable process. However, the opponents of détente in Western countries had recently become active, and the Communist states needed to do everything they could to preserve what had already been achieved. Since the Vienna talks, representatives of the Western countries had from time to time raised the idea of a reduction of military forces that would encompass Hungary. With the purpose of reassuring the Soviet Union, Kádár made a point to confirm that the Hungarian position was unchanged: Hungary would participate in the reduction only if Italy was also included.

Obviously aware of the Soviet-Romanian agreement made in the meantime, Kádár resubmitted his former proposal to establish the Council of Foreign Ministers. Giving up the veto on which he had insisted for so long, Ceauşescu agreed this time to establish the council, which officially began its work in 1976.

Of all the speeches delivered at the summit meeting held from 30 July to 1 August 1975 to sign the Helsinki Final Act, Kádár's speech was one of the most remarkable contributions. Among the socialist countries, Kádár spoke in greatest detail about the issues in the third basket as well as the topic of European cooperation. The latter was greatly appreciated and cited by the contemporary Western press. Kádár devoted roughly one-third of his speech to cultural cooperation and exchange of information, doing so in a positive manner. He used convincing-sounding data to convey Hungary's interest in facilitating foreign travel and personal interactions. He stated that each year eight million visitors came to Hungary, a country of ten million inhabitants, and more than three million Hungarians traveled abroad.

In another striking aspect of his speech, Kádár strongly emphasized the attachment of Hungary to Europe. What was truly unprecedented was that the Hungarian Communist leader spoke openly about the Trianon syndrome, explaining that Hungary had lost two-thirds of its territory after World War I. ${ }^{98}$ All those present knew that the majority of the territory cut off from Hungary had been taken by four neighboring countries, all of which had come under Communist rule in the 1940s, and three of which were members of the Warsaw Pact.

Hungarian leaders remained active after signing the Helsinki Final Act. The MSzMP Political Committee adopted a detailed resolution at its session on 15 August 1975 concerning the near-term obligations that derived from

98. The peace treaty signed in the Grand Trianon palace in Versailles in June 1920 deprived Hungary of two thirds of its territory and one third of its Hungarian population. 
signing the Final Act. ${ }^{99}$ The resolution stemmed from Hungarian leaders' view that they were in a relatively good position to apply the provisions contained in the Final Act and could therefore "actively and offensively" act in the field of bilateral relations. In accordance with the resolution, Hungarian officials were instructed to work out proposals for the development of economic and cultural relations with Western states, and preparations had to begin promptly for a series of talks to be held in Belgrade in June 1977. Shortly afterward the party published 100,000 copies of Kádár's speech and the full text of the Final Act. ${ }^{100}$

Hungary ostensibly benefited most from the security conference in the Soviet bloc, as well as from the evolving rapprochement. The success of the Helsinki process provided an excellent opportunity for Hungary to pursue closer relations with the West, which became crucial for the country's economic well-being. The post-Helsinki human rights campaign initiated by the U.S. government under Jimmy Carter affected Hungary the least among the Warsaw Pact states. Moreover, the continual appraisal by the West at Helsinki review conferences led to an upgrading of conditions in Hungary. The Hungarian government was quick to take advantage of the situation. In 1976, when a "package" of proposals was dispatched to nineteen Western countries (including the United States) calling for intensive development of bilateral, political, economic, and cultural cooperation, Hungary was the only Soviet-bloc country to participate. ${ }^{101}$

Consequently, Hungarian relations with the West markedly improved, and from the second half of the 1970s onward a series of visits on the highest level followed. In 1977 Kádár visited Bonn and Rome, and in 1978 he traveled to Paris. In 1977 French Prime Minister Raymond Barre paid a visit to Hungary, as did West German Chancellor Schmidt in 1979. At the CSCE review conferences in Belgrade, Madrid, and Vienna, Hungarian diplomats played an increasingly active role. Fittingly, the only follow-up conference that took place in a Warsaw Pact state was the European Cultural Forum, held in Budapest in 1985.

99. Minutes of the HSWP Political Committee, 12 August 1975, in MNL-OL, M-KS. 288, F. 5. cs. 670. o.e.

100. Az Európai Biztonsági és Együttmúködési Értekezlet záróokmánya (Budapest: Kossuth, 1975).

101. See the relevant documents in MNL-OL, M-KS. 288, F. 32/1985, Box 15. For an English translation, see Békés and Locher, eds., Hungary and the Warsaw Pact, 1954-1989. 